Article

\title{
Green to Gold: Beneficial Impacts of Sustainability Certification and Practice on Tour Enterprise Performance
}

\author{
André Hellmeister ${ }^{1}$ and Harold Richins ${ }^{2, *}$ \\ 1 International Online Marketer, RED Online Marketing, 3433 EP Nieuwegein, The Netherlands; \\ andre.hellmeister@gmx.de \\ 2 Faculty of Adventure, Culinary Arts and Tourism, Thompson Rivers University, 805 TRU Way, \\ Kamloops, BC V2C 0C8, Canada \\ * Correspondence: hrichins@yahoo.com
}

Received: 5 October 2018; Accepted: 15 January 2019; Published: 29 January 2019

check for updates

\begin{abstract}
A growing number of managers in tourism recognize the importance of sustainability to their business success. However, as the majority of tourism enterprises consist of small and medium-sized enterprises that are generally less likely to invest in sustainability practices due to a lack of financial resources, time, and perceived cost-saving opportunities, an industry-wide dissemination of sustainability practices is hampered. This paper explores the benefits of adapting sustainability practices and provides evidence for making the case for incorporating sustainability practices to benefit business success. This study examined sustainability-certified tour enterprises, focusing on the perceived impact that the commitment to sustainable practices through certification has had on tangible financial aspects (potential benefits of increased revenue and decreased operational costs) and intangible benefits (customer satisfaction and employee satisfaction). Also explored were the influence of strategic choices related to sustainable practices (extent of commitment, product range, facilities and equipment, and the application of relevant marketing practices). Study findings were encouraging, identifying cost-savings, increased revenue, enhanced reputation, and customer and employee satisfaction. Energy-savings as well as a greater connection to the community were found to be beneficial outcomes of sustainable practices. Despite its acknowledged dependency on the natural environment as well as cultural assets nature and culture, the tourism industry is perhaps still in its infancy in moving towards industry-wide sustainability success. While academic literature has attributed this to the lack of awareness and low dedication to take action, this study found an indication of a positive relationship between sustainability commitment and financial and non-financial firm performance. The findings extend previous research that focused on larger and more facility-dependent enterprises and suggest that sustainability is a beneficial path to follow regardless of company size and budget.
\end{abstract}

Keywords: sustainability certification; tour enterprise performance; business case of sustainability; sustainable tourism

\section{Introduction}

Globalization and the growing public awareness of climate change have led to a consumer culture that values social and environmental sustainability. Following this public interest, there has been an unprecedented increase in companies that take pride in sustainability-awards, certifications, and initiatives that support charitable causes in recent years. Calls for transparency and media coverage of shortcomings in sustainability resulted in a shift in business models, moving away from historic approaches [1], where a business' only responsibility was to increase profits. Rather, there has been 
movement toward valuing other parties as discussed in Freeman's Stakeholder Theory [2], which sees profit as a logical result of pleasing the interests of customers, suppliers, communities and other involved parties, and this approach has made its way into discussions on executive corporate boards.

Businesses may adopt sustainable practices for a number of reasons, including ecological and social altruism, compliance with regulations, competitiveness, risk and brand management, profit maximization, cost reduction, product development, and customer pressure [3-8]. While the most frequently cited motivation factors among larger corporations for adopting sustainable practices are cost cutting and reputation management [9], the motivations among tourism SMEs (small and medium sized enterprises) are 'to protect the environment' (87\%), 'personal/lifestyle choice' (49.2\%), 'improve our society' (46.9\%) and 'cost-savings' (29\%) [5]. Hence, the decisions against implementation of sustainable practices seem to be based on financial values, while the ones for implementation are based more often upon ethical values.

In order to move the remaining non-ethically-driven companies towards sustainability, several strategies on the minimization of tourism environmental impacts have been undertaken or proposed. Voluntary Carbon Offset Payments have been tried, but deemed less than effective [10,11], as the majority of consumers are not willing to pay extra, given a choice. Another potential solution, Compulsory Carbon Offset Payments, was proposed [12], adding \$11 per trip [13]. However, even though this represented less than $0.1 \%$ of the estimated global tourism economy in 2020, the calculation has shortcomings. The $\$ 11$ would need to be paid for every trip, disregarding its length, distance or market economy. Hall [14] advised the concept of Steady State Tourism, which is a destination development strategy that encourages qualitative development but not quantitative growth. Willingness to pay has also been notably explored, which can provide an understanding of the customer in their willingness to pay a premium for organized tours that demonstrate a commitment to significant environmental practices [15-19].

Another option is overall stronger (global) government regulation. In recent years, in the European Union, governments have jointly stepped up to passing laws that require sustainability reporting (environmental and social practices) for companies of public interest with more than 500 employees [20]. However, the method of reporting is normally determined individually, by the respective companies, leaving room for self-benefitting interpretations. To overcome this potential for greenwashing, governments in France, UK and Germany, as well as businesses such as Walmart and non-governmental organizations, like the World Wildlife Fund (WWF), have begun to call for the implementation of some form of meta scheme that condenses existing product labels [21]. Under a broader framework, the UNDP 2030 Agenda for Sustainable Development's SDGs (Sustainable Development Goals) have provided a more comprehensive structure for consideration and concerted action [22]. In considering SDGs, research proposed that environmental certifications may be a more effective tool in creating positive social change than government regulated CSR (Corporate Social Responsibility), such as carbon taxes [23].

A growing number of managers in tourism enterprises recognize the importance of sustainability to their business success [5]. However, as the majority of tourism enterprises consists of small and medium-sized enterprises that are generally less likely to invest in sustainability practices due to a lack of financial resources, time and perceived cost-saving opportunities, an industry-wide dissemination of sustainability is hampered.

This paper explores the benefits of adapting sustainability practices for tour enterprises and seeks to provide evidence for the business case of sustainability. While research exists on impacts related to lodging, this study more specifically examines broader tourism industry sustainability-certified tour enterprises.

The primary research question for the study was to look at how the commitment to sustainability affects tour enterprises' financial and non-financial firm performance. This included tangible, that is, material benefits that may influence financial firm performance, such as examining the impact sustainability commitment has on (1) revenue (customer numbers and customer spending), and (2) 
operational costs (influenced by cost savings through increased resource-efficiency, but also increased costs due to extra work on sustainability-related projects).

Also explored are less tangible benefits that may influence a tourism enterprise's long-term performance. More specifically, the impact sustainability commitment has on both customer satisfaction (potentially leading to increased customer numbers and spending) and employee satisfaction (potentially leading to increased productivity, increased loyalty and attraction of talent) is explored. Finally, in order to understand more differentiated types of tourism operations, comparisons were drawn based on the extent of commitment (consisting of implemented practices, years of commitment), the product range, the degree of facilities and equipment, and the extent and types of marketing and communications employed.

\section{Effects that Sustainability Practices Have on Financial and Non-Financial Firm Performance}

As there is limited literature on the effects that sustainability practices have on financial and non-financial firm performance regarding tour operators, the following considers tourism in general, as well as across other industries. The areas of discussion include sustainability and firm performance, cost savings due to sustainable practices, potential for increased consumer demand and willingness to pay, differences in market segments and sustainability influence, challenges and effectiveness of marketing and communication regarding awareness of sustainable practices, confusion regarding types of certification alternatives, and employee commitment to practices. These are discussed further below.

Sustainability and firm performance. Across all industries, previous literature on the relationship between sustainability-related actions and firm performance is inconclusive, finding positive, neutral and negative associations [24], varying across firms and considered parameters [25]. Regarding the short-term, sustainability-related actions are connected to increased costs [26], while for the long-term, benefits such as improved reputation and the avoidance of future retrofits may be an advantage as companies stay ahead of future regulatory requirements [27]. Moreover, as the environmental values of the company and its employees align, levels of employee satisfaction may increase and result in increased productivity and talent attraction [28].

There are a limited number of tourism-focused articles that address firm performance based on sustainable activity, mostly focusing on hotels, and fewer analyzing tour operators. It can be argued that the results for hotel operators are similar to other industries. Though a positive impact of sustainability-related actions on firm performance has been indicated in these hotel studies, it has not often been considered robust [24,29-31]. Only one study found negative impacts [32], however this was presumably due to the rather small geographical scope, as a similar study conducted two years later by the same authors with a larger geographic scope, found a positive impact [29]. Though there has been some uncertainty regarding impact [33,34], the source of the eco-label, that is whether from government or NGOs as compared to corporate or corporate association established eco-labels, has been found to be an indication of credibility and trustworthiness in the green market [33,35].

Cost savings due to sustainable practices. Cost-savings are widely recognized across all industries as the typical initial benefit of implementing sustainability, as the sole nature of saving resources in the production process yields immediate cost-savings, which in turn can be used to steadily reinvest in further measures [36]. To overcome larger investment costs for technical solutions (e.g., solar panels), firms usually start with low-cost/no-cost options, like the "3 Rs" (reduce, reuse, and recycle) or follow guidelines provided by numerous NGOs, industry associations, and sustainability scheme providers [37-39]. Moreover, costs can be saved by applying for government incentives (e.g., lower taxes, investment subsidies) and by receiving lower interest rates for loans and insurances [27]. Hence, the argument of 'lack of money' as a barrier to sustainability can, over time, be circumvented. This is supported by research of pro-environmentally active SMEs, which found that $73.6 \%$ of SMEs reportedly experienced cost-savings as a result of their efforts [8].

Though cost-savings is both an incentive and a benefit, there is great diversity within the tourism industry in terms of resource use $[40,41]$. Generally speaking, the highest amount of cost-savings can 
be expected for facility-focused enterprises, such as hotels. While hotels can reduce energy costs by $20-40 \%[42,43]$ without affecting performance [44], tour operators have less cost-saving options, due to their lower amount of resource use [45].

Potential for segmentation, increased consumer demand and willingness to pay. Studies on the consumer demand for sustainability-related tourism products and the willingness to pay are characterized by a large attitude-behavior gap. Depending on the formulation of the questions, consumer demand for sustainable options for "want more responsible holidays" was found to reach up to 75\% [46] and 71\% for "plan to make more eco-friendly choices" [47]. When asked about actual behavior on past trips, percentages fall to $36 \%$ [48] and 38\% respectively [47] with only $9 \%$ out of the $38 \%$ specifically seeking out products because of sustainability desires, and the rest stayed in an environmentally-friendly hotel unintentionally. Moreover, of all interested tourists, about half are willing to spend a $10-15 \%$ premium and the remaining only as much as $5 \%$ [49] to support sustainable practices.

According to one study on market segmentation based on the tourists' "sustainable intelligence," tourists are not willing to pay, because they believe that the government should cover investment costs or companies should pay through their cost-savings [50]. Nonetheless, the high general interest implies that tourists expect companies to build sustainability into their product offerings, and its importance can best be described with a quote from the World Travel \& Tourism Council [51]:

"Travelers are coming to expect that tourism businesses will become sustainable in the same way they expect free Wi-Fi connectivity in hotels or online check-in for air travel."

The kind of products consumers value, are more likely to be the ones that directly benefit the consumer's individual well-being [52], such as unpolluted air or healthy organic food.

Challenges and effectiveness of marketing and communication regarding awareness of sustainable practices. Marketing of sustainability is a complex topic and at the heart of this process are issues of trust in the credibility of advertising in general, and in environmental claims in particular [53,54]. It was found that products marketed for their sustainability characteristics may be perceived to have substandard product performance [55] and that publicly stressing the sustainable benefits can reduce likability [56].

The awareness of this has led companies to deliberately under-communicate their actual good practices [57] labeled as "greenhushing" being the new "greenwashing." Examined companies were found to communicate only $30 \%$ of all of their sustainability actions. This practice may result in lack of awareness among consumers, as found by a survey by Kwan, Liu \& Mak [48], where more than $50 \%$ of respondents were unsure whether they had stayed at a green hotel or not. In addition, the use of green advertising (in print and TV) may result in credibility issues irrespective of whether their claims are valid or not [58].

However, it has also been argued that the majority of marketing managers do not understand how to market sustainability $[59,60]$, and possibly make the same missteps as they did decades ago [61]. Commonly used communication tends to be focused on factual and descriptive, product-based messages that focus on what they do, but do not speak effectively to the needs and preferences of consumers. Instead of highlighting the company's benefits or benefits for the earth or society, consumers are most interested in what benefits them personally [62-65]. Generic claims like, "we operate sustainably/green/etc" are far less credible than specific messages communicated in an appealing style $[35,62,66]$.

Confusion regarding types of certification alternatives. A common approach to gain the trust of consumers is third-party validation like news coverage, affiliation with respected non-profit or civic organizations, and certification. While most of these are difficult to achieve, certification can be a strategic goal. Starting around 1990, about a dozen certification schemes were set up to protect customers and benevolent businesses [67], but with over 465 today [68], this plethora of different labels quickly became more confusing than beneficial. According to Hamele [69], there are approximately 140 sustainability certifications in tourism. The general confusion surrounding this vast number of labels has subsequently provoked strong competition for the more popular labels and awards. 
Employee commitment to practices. Research has shown a high correlation between corporate social responsibility and employee engagement [70] and with increased societal interest in meaningful work, companies may yield benefits by aligning their business interests with the interests of their employees and society at large [71]. Companies that emphasize CSR have gained a significant rise in morale as well as loyalty [30,72,73], and employees spend more time at work [74]. Employees also have greater faith in management [75], deliver increased productivity [76], and engage in enhanced teamwork [75] and planning relevant to sustainability $[70,77]$.

\section{Methodology of the Study}

The research discussed in this paper evaluates, through a survey of expert opinion, the perceived impact that the commitment to sustainable practices through certification has on tangible financial aspects (potential benefits of increased revenue and decreased operational costs) and intangible benefits (customer satisfaction and employee satisfaction). The influence of strategic choices to sustainable practices (extent of commitment, product range, facilities and equipment, and the application of relevant marketing practices) was also explored.

In order to quantify the benefits of sustainability commitment, a review of secondary literature helped to develop a thorough understanding of the factors that influence performance in general and for tour enterprises in particular. Nonetheless, as tour operator-specific research is still limited, this research is of an exploratory nature. Data was collected by means of an online survey, which was pilot tested by relevant industry practitioners who either had significant work experience with a focus on tour operator sustainability or worked in a management position at a tour enterprise which had made a commitment to sustainable practices, thereby having knowledge in the specific areas related to this study. The first round aimed at improving the survey questions and was done by two professionals from Travelife for Tour Operators, whose work revolves around providing training sessions, holding audits, and awarding certification to sustainable tour operators. With their feedback worked into the research design, a final pilot test was conducted with a sustainability manager of a tour enterprise, to test clarity of the survey questions. The final survey was sent using the online survey tool Qualtrics, and subsequently analyzed using the analytics functions within Qualtrics, as well as Microsoft Excel to further analyze exported raw data from Qualtrics.

The survey questions explored the motivating factors for commitment and were set out as both nominal questions and ranking questions (People vs Planet vs Profit). Implemented social and environmental measures utilized nominal questions. Based on the choices indicated by the respondent, another question requested that the respondent rank the employed practices from most to least beneficial to the company's financial performance and from most to least appreciated by customers and employees. An optional open-ended question on best practice was then asked to provide further analysis. The financial performance indicators (revenue, costs and profitability) were measured specifically in relation to the direct impact of sustainability commitment, in order to exclude contextual influencing factors of business success. Moreover, as the sample population largely was comprised of small to medium enterprises (SMEs), and hard data on many non-financial indicators were not recorded, these were measured based on perceived changes, employing interval scale questions with a 6-point Likert scale or percentages. Then, several motivating factors for sustainability commitment were covered, ranging from the attracted target markets' age groups and origins, to employed marketing actions and the formulation of the communicated messages, and revenue share accountable to sustainability-related products and services.

The survey also inquired about general company data, including the type of business in which the company operated (inbound tour operators, outbound tour operator, other), the years in business, years of seriously committing to sustainable operations, and-if applicable-the year in which certification, or other types of recognition were attained and the number of employees to indicate firm size. The survey ended with a question on the important effect sustainability has had on the company's success since business creation, at present and is expected to have in the future. 
In order to reach the companies that indicated a robust commitment to sustainability and hence a considerable amount of sustainability practices employed, the population was chosen as: sustainabilitycertified companies. To approach them, nine certification scheme providers with certification programs covering tour operations were contacted as intermediaries. Most of the approximately 140+ [69] certification schemes within the tourism industry are not focused on companies but confined to beaches, nature reserves, to entire holiday regions, or are self-awarded labels. This research narrowed the field to the twenty largest, overarching quality labels as identified by the report 'Sustainability in tourism: A guide through the label jungle' [78] and utilized these certification schemes, Nine of these certify Tour Operators with varying amounts of certified companies per label. The two largest - Ecotourism Australia (192 companies) and Travelife for Tour Operators (191 companies on an international scale) represent over two thirds of all known certified companies in this research. Of the 566 tour operators contacted, which covered operations in a diversity of locations internationally, 104 responded to the survey.

The results presented nine major aspects relating to sustainability commitment and performance, including: (1) general company characteristics, (2) commitment to sustainability, (3) motivating factors, (4) marketing practices of commitment to sustainability, (5) most beneficial of sustainability practices, (6) investment costs in sustainability practices, (7) annual operating costs and potential return on investment, (8) perceived benefits of a commitment to sustainability practices, and (9) perceived overall importance of sustainability practices to business success.

\section{Results of the Exploratory Study}

(1) General company characteristics: Companies in the respondent group were found to be of various sizes and characteristics. Of the majority of responding tour operators, about two thirds facilitate inbound tourism, with close to one-third focusing primarily on outbound tourism. The distribution between companies offering day trips (36) and multi-day tours (42) is relatively balanced. Size is based on the number of employees, varied between 0 and 34,000 employees (see Figure 1). However, $99 \%$ of the companies indicated fewer than 500 employees, $82 \%$ employ 50 or fewer employees, $52 \% 10$ or fewer. Five companies said to employ more than 200.

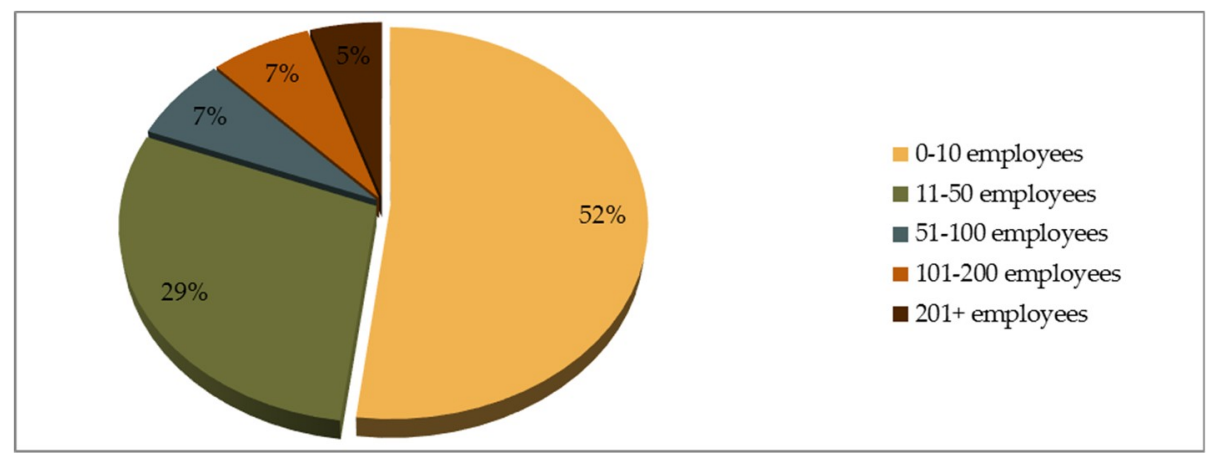

Figure 1. Number of employees.

Tour operators in the study have been in operation close to 18 years on average, and, while the oldest has been in business since the 1950s, and the most recent has been operating for two years, the spread is relatively even (see Figure 2).

(2) Commitment to sustainability. Commitment to sustainability has gained momentum, especially over the past 10 years. Certification in turn is a more recent trend for respondents in the study, with $74 \%$ having attained their certificate within the past 5 years and $53 \%$ within the past two years (see Figure 3).

(3) Motivating factors: The findings for motivating factors highlight that the commitment to sustainability is foremost an affair of the heart (emotional relationship or commitment), and then a business-minded decision. The motivating factor 'Protecting the environment' was found to be 
the most common motivation, followed closely by 'Improve society' and 'Personal/lifestyle choice'. Business-driven motivations were less often named as motivating factors (see Figure 4). Examples of comments reinforcing their motivations regarding this commitment:

\section{"Protection of wildlife"}

"Thailand doesn't have very many eco-laws, so we make our own."

"For now a good marketing tool, but in a few years we believe that without a sustainability certificate we are out of the market."

"It is all about bringing awareness to people."

An additional influencing factor on customer numbers and spending on sustainable tours has been identified as customer age \& origin. The study reviewed whether there were differences in motivational influence based on these factors and found no significant difference.

(4) Marketing practices of commitment to sustainability: Besides displaying the attained certificate on the companies' websites, no marketing practice is employed consistently throughout the sample (see Figure 5). Somewhat more than half of the surveyed tour enterprises include sustainability showcasing as marketing tools, which are shown in travel itineraries $(64 \%)$ or exhibit further details of their actions online $(54 \%)$, while third party validations are only used by $27 \%-43 \%$ and $30 \%$ organize or sponsor events for local communities.

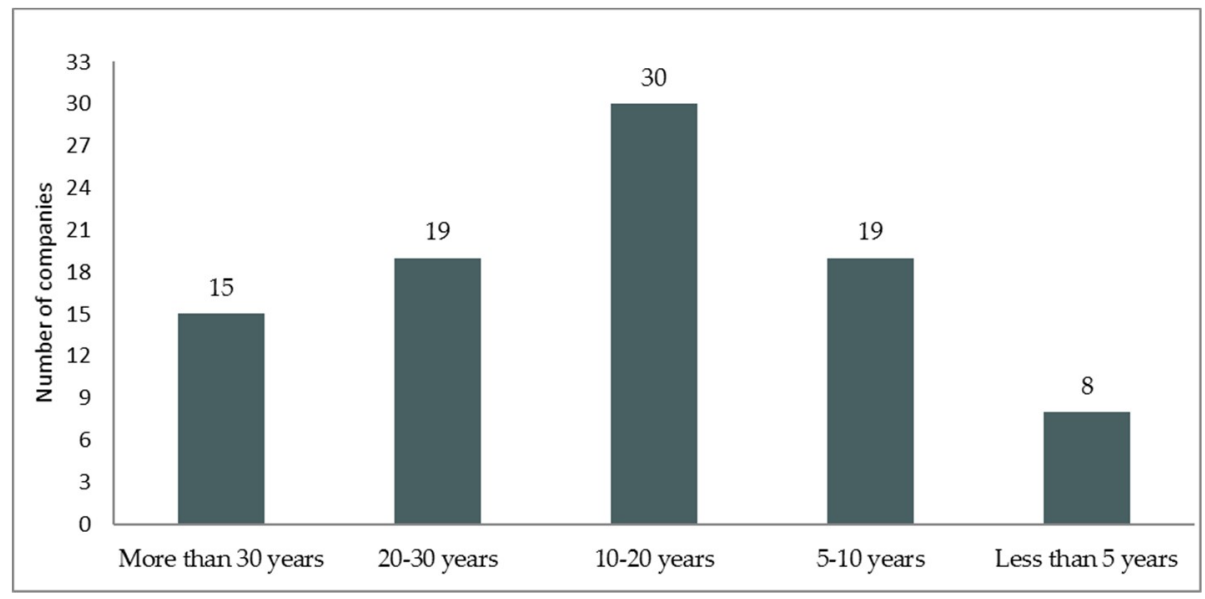

Figure 2. Years in business as a tour operator.

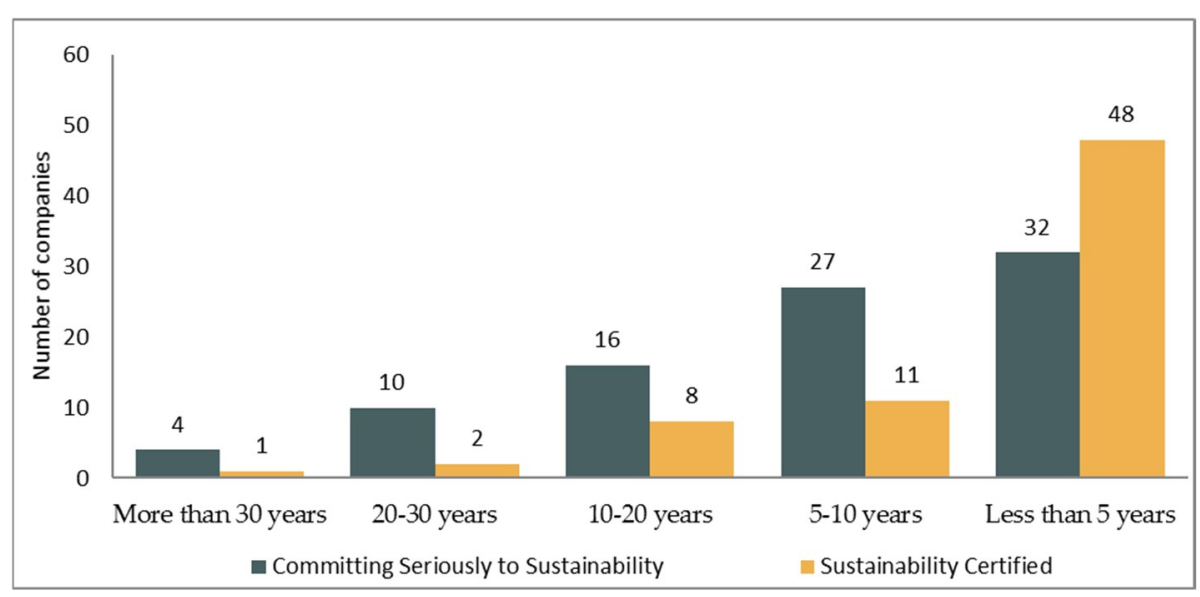

Figure 3. Sustainability commitment and certification over time. 


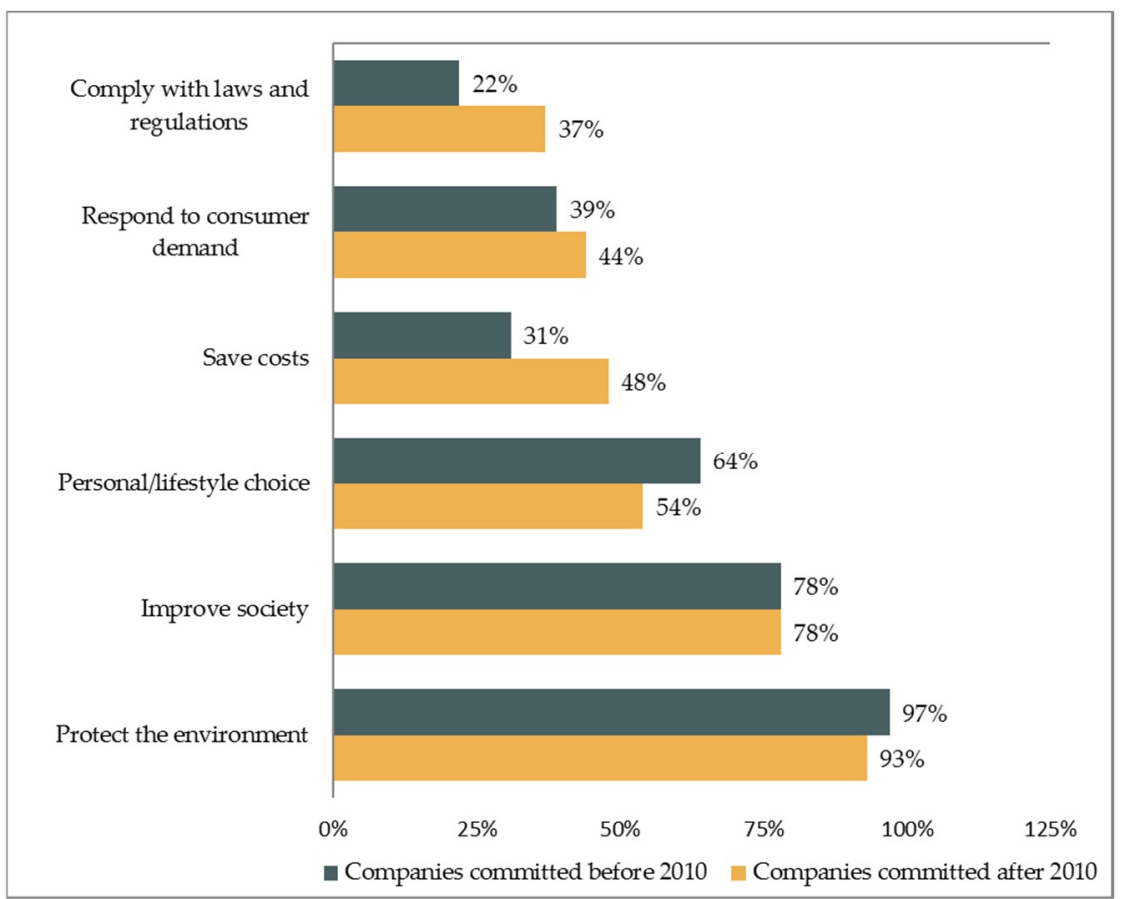

Figure 4. Motivational factors in the commitment to sustainable practices.

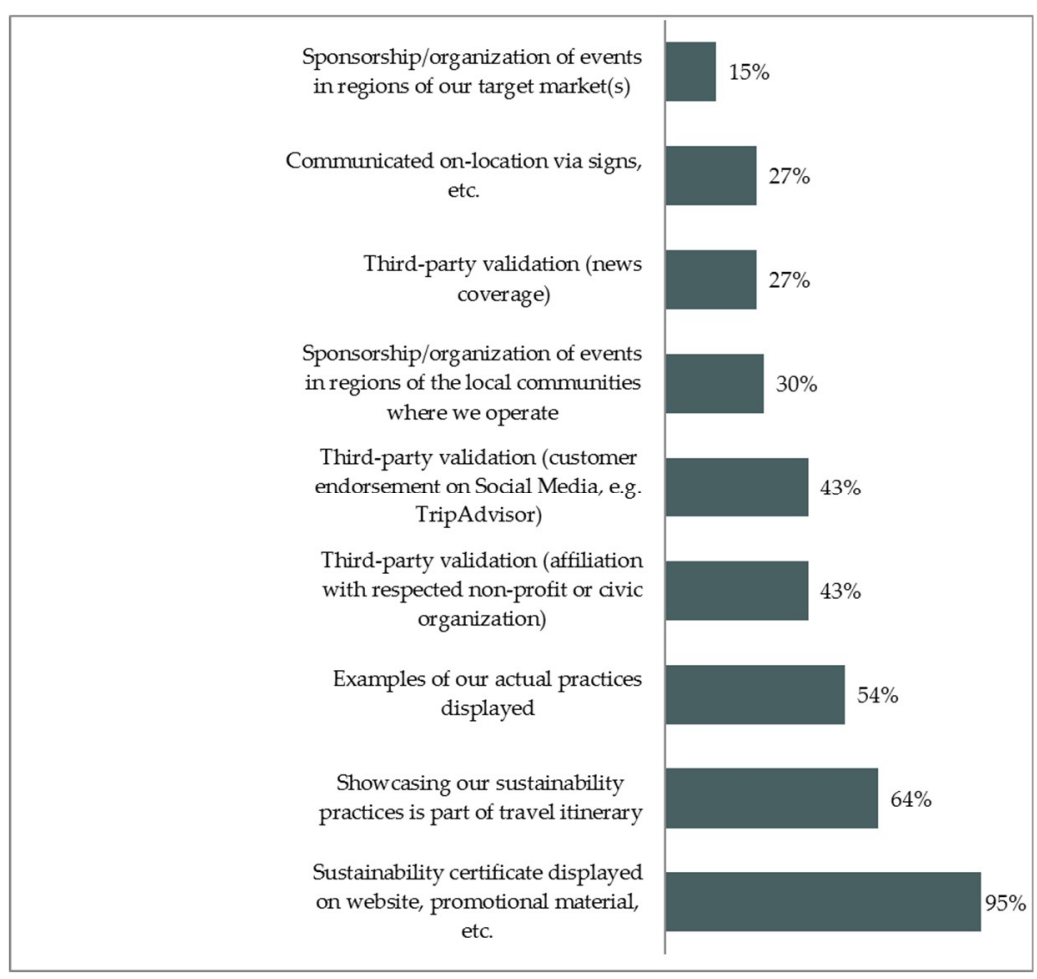

Figure 5. Indicated marketing practices of commitment to sustainability.

(5) Most beneficial of sustainability practices: Based on each company's respective implemented practices, respondents were asked to rank the three most beneficial in terms of social and financial return on investment (see Figure 6). This figure shows the number of times that a respondent mentioned various sustainability best practices as the number 1st, 2nd or 3rd most important in benefiting the tourism operator. The most often indicated best practice is 'energy-saving', followed by four which 
were nearly evenly rated: 'water-saving', 'encourage customers to be environmentally friendly', and 'choose environmentally friendly suppliers, 'encourage customers to consumer/use local products'.

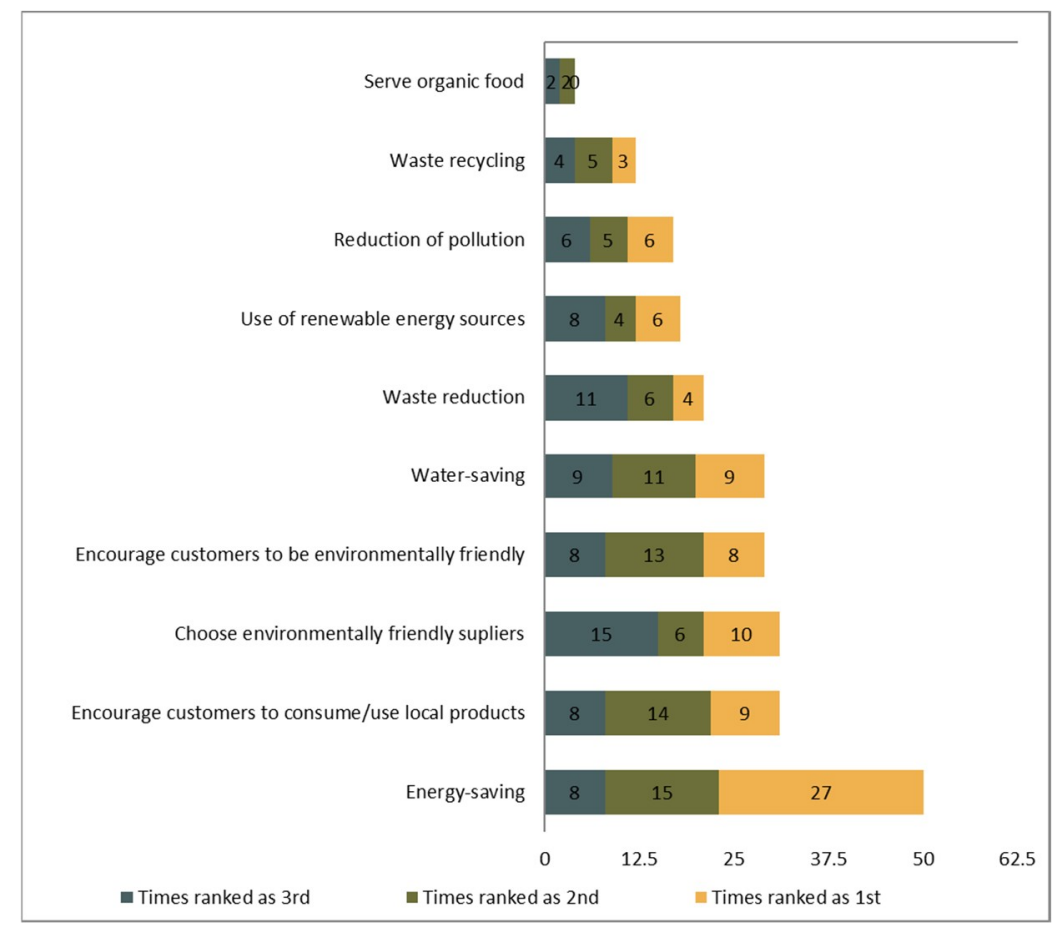

Figure 6. Most beneficial sustainability practices indicated.

There are some differences, however, in comparing the most beneficial sustainability practices of the respondents with those implemented. Possibly a more accurate presentation is the percentage of companies that have a certain practice both indicated as both beneficial and implemented. In the depiction below (see Figure 7), the percentage on the yellow bar represents the respondent's top three most beneficial practices, while the dark bar represents the practices implemented by the various certified tour operators.

While the majority of the most beneficial practices remain in the same order as in the above diagram, one other practice stands out: 'Use of renewable energy sources', which is not as commonly implemented, but is viewed as a likely way to generate benefits.

(6) Investment costs in sustainability practices: Almost all respondents (95.2\%) have invested funds of varying amounts into the environmental and/or social sustainability of the company's operations. However, the indicated amounts range from $\$ 119$ to $\$ 300,000$. For further analysis the outlier $(\$ 300,000)$ has been excluded from the calculations, as well as companies who did not provide their investment costs. Based on the remaining sample (91\% of original sample), the mean invested is $\$ 7099$. Moreover, to illustrate the spread, groups based on amount ranges have been formed (see Figure 8).

(7) Annual operating costs and potential return on investment: To analyze the potential of financial return on the initial investments, companies were asked about sustainability-induced changes in their annual operating costs. Self-proclaimed by the respective managers, the increases and the decreases added together summed up to the following results. While $88.8 \%$ claimed having saved costs, $85.2 \%$ claimed to have additional costs. Although this is generalizing the complexity of investments, it could be argued that the $\$ 7099$ mean of implementation costs can be recovered over time, with the sum of claimed financial benefits and deficits concluding in an annual cost recovery of $\$ 1,602$, theoretically leading to a full recovery of initial investments in the fourth year. This suggests that the financial impacts on the responding companies were overall positive; hence financial company performance is improved after sustainability investments were made. Furthermore, this calculation did not take into 
account increased customer numbers, increased customer spending, or length of stay, as those were collected using Likert scales, not as financial values. While some respondents indicated sustainability to have a positive impact on customer numbers (12.2\% of respondents), customer spending $(16.5 \%)$, and length of stay (19\%), most respondents saw no change; only $2.2 \%$ experienced a negative impact, forming overall encouraging implications.

(8) Perceived benefits of a commitment to sustainability practices: Next to the tangible benefits of cost savings and increase in revenue, the implementation of sustainability entails several intangible (long-term) benefits. All areas were rated more often as positive (534 times 'much better' or 'somewhat better'), than negative (13 times 'much worse' or 'somewhat worse'), as compared to 'about the same' (253 times mentioned) (see Figure 9).

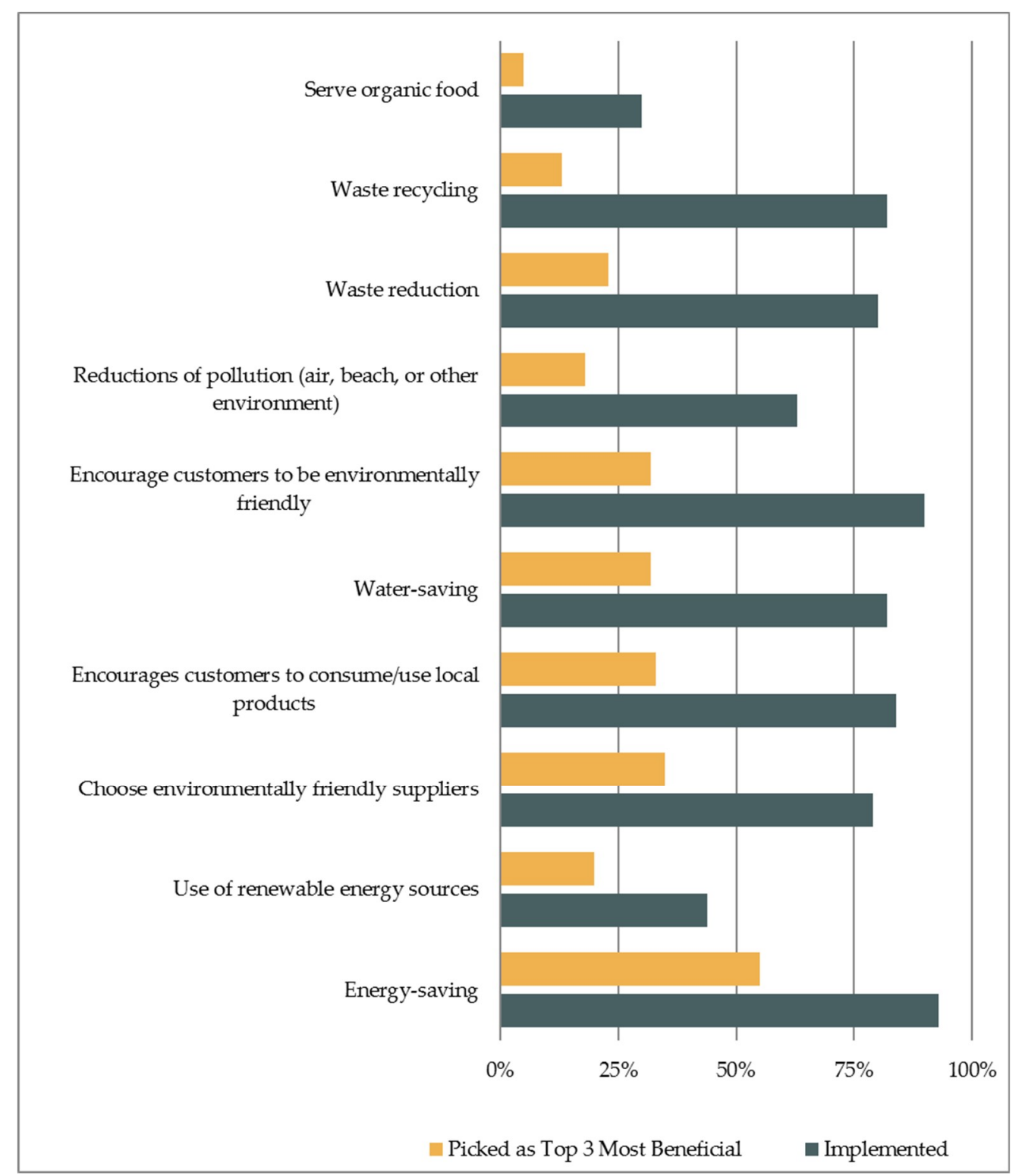

Figure 7. Most beneficial practices indicated vs. those implemented. 


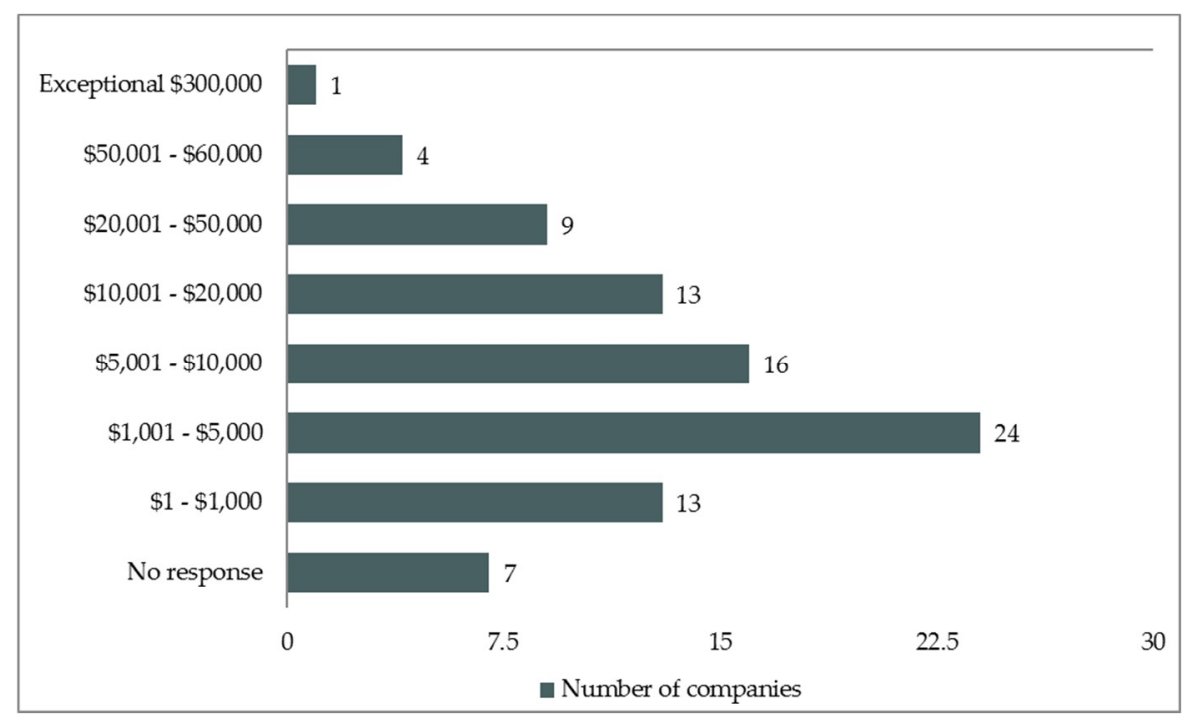

Figure 8. Investment costs in sustainability practices.

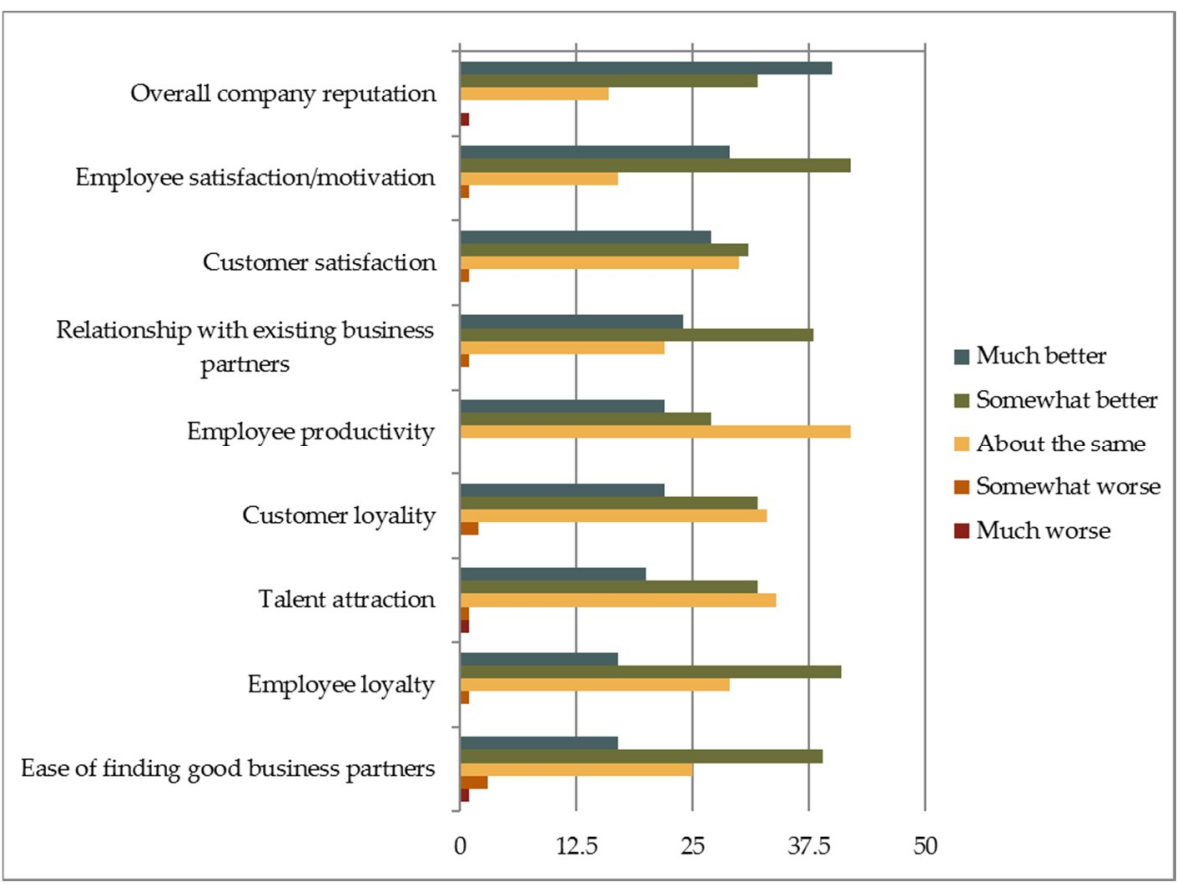

Figure 9. Perceived intangible benefits for commitment to sustainability practices.

Based on the self-perception of managers, company reputation was rated with the highest improvement (45\% 'much better'; 36\% 'somewhat better') and received as well one of the lowest counts for negative and equal ratings. The second most positively rated aspect of improvement is employee satisfaction with $45.2 \%$ answering 'somewhat better' and 32.6\% 'much better' (see Figure 10). This, however, needs to be validated by further research. Other improvements are seen in the relationships with business partners, employee loyalty, and customer satisfaction \& loyalty. While no area could be considered significantly negative, employee productivity received the least positive outcome with 22 'much better' responses, 26 'somewhat better', and 42 'about the same'.

(9) Perceived overall importance of sustainability practices to business success: Sustainability practices are largely perceived by respondents to be of high importance to the overall business success (see Figure 10). The highest importance is seen 'in future', with $87 \%$ of managers giving it the highest 
possible selection on the Likert scale. Receiving certification is seen as slightly less important than 'seriously committing to sustainability', but still is rated by $75 \%$ as a 5 or 6 .

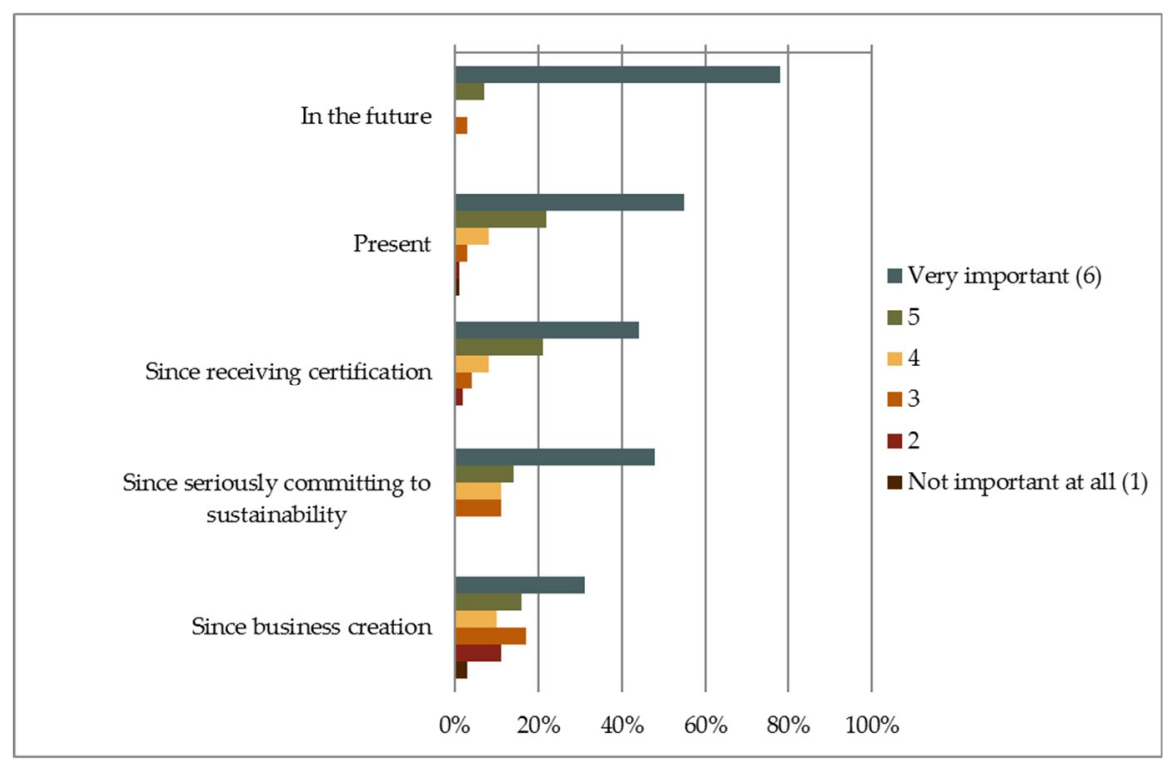

Figure 10. Perceived overall benefits to business success.

\section{Discussion and Conclusions}

The collected survey data of this exploratory study is encouraging and suggests that sustainability commitment on the Civic and Strategic level both serve to create value [79]. While it would be difficult to draw conclusions on the tour enterprise industry at large, or to suggest that sustainability among tour operators is as much of a trend as it is among accommodation businesses [80], the findings do indicate that sustainability commitment and certification has been gaining momentum over the past years and that it has been predominantly beneficial to the companies' overall success. Moreover, the notion of adopting social sustainability—in ways that empower employees and communities-serves as a positive example of the Shareholder Theory [2].

Motivations of the majority of sampled companies are in line with findings of Font, Garay, \& Jones' [5], depicting that sustainable SMEs are largely lifestyle-driven and value social and environmental benefits to a greater degree than financials. However, it seems as if a global tightening of legal restrictions and consumer demand increasingly attracts commercially motivated enterprises in a gradual shift from the relatively small eco-niche tourism companies towards more mainstream tourism operations.

Moreover, implications of sustainable practices on increased revenue through higher customer numbers, spending and length of stay were found to be positive. This varies somewhat from previous studies which indicated more nominal increases in customer spending and length of stay [46-48,81]. Nonetheless, sustainable practices have a positive impact on customer satisfaction, which potentially leads to referrals and increased customer numbers.

Regarding satisfaction of staff and subsequent benefits to the firm, based on enhanced sustainability practices, improvements in loyalty [72,73] and talent attraction [28] were found to be similar to the literature, and so was employee productivity, though with lesser emphasis.

The expected influencing factor 'quality of marketing messages' and their effects on a rise of customer numbers, spending and length of stay, were found to be inconsequential. While this might be due to the aforementioned lack of credibility of sustainability-related marketing messages in general [36,63-67], the mere $4 \%$ of responding companies who utilized all of the suggested favorable marketing messages provide less evidence to reveal clear indications. 
Differences in motivational influence of sustainability practices based on age and origin were explored in the study. Following a Nielsen Company's survey in 2015, which found that firms whose customers come predominantly from emerging market economies and/or are predominantly younger in age, are more likely to have a willingness to spend. However in contrast, no significant relationship was found in the present study. An explanation for this could be a similar attitude-behavior gap, as it was found in studies focusing on customer willingness to pay [47,48] and actual past payments $[47,48]$.

Concerning applied marketing channels, about half of the responding companies do not go further than displaying the certification-label on their website, which is in line with Font, Elgammel \& Lammond's [57] understanding of "greenhushing," and indicates that a large amount of companies under-communicate their actual practices. However, if companies are under-communicating out of concern to be perceived to offer substandard product performance [55], or lose likability by boasting about their achievements [56], it may be worth considering the two-thirds of respondents who make transparent their sustainability practices in tour itineraries. This practice turned out to be of significant advantage as an influencing factor of customer satisfaction, which is in line with Kachel \& Jenngings' [82] study on the social reconstruction of environmental values through travel experiences and its influence on tourist satisfaction.

The limitation of this research lays in the source of the data, as it is based on claims and perceptions of company managers. Their perceptions about employee satisfaction and / or financial figures may only be estimations. Nonetheless, the results are an indication of benefits, as respondents are predominantly positive about the impacts their sustainability engagements have brought about.

The present study found a positive relationship between sustainability commitment and financial and non-financial firm performance in all examined areas. This perhaps extends previous research on the possibilities for sustainability implementation among SMEs in general and facility-independent enterprises in particular.

\section{Implications and Recommendations for Future Research}

The findings of this exploratory study emphasize the business case for sustainability in tour operations, as well as the potential for forward movement of sustainability commitment and certification in mainstream tourism. Moreover, it signifies a tool for increased promotion and awareness of sustainability certifications and their respective benefits for the tour operators specifically, and more broadly for tourism enterprises. This may help build upon, and strengthen the incentive for both sustainability accreditation schemes and even more importantly, the commitment, investment and outcomes of sustainable practices regarding tour operations.

Recommended future research could investigate ways in which community involvement impacts firm performance, as well as the return on investment of specific practices. Moreover, efforts as shown in the present study could be extended to compare actual increases or decreases of customer numbers, spending, and length of stay between sustainability-oriented and non-sustainability-oriented companies within a limited geographic area in order to minimize most external influencing factors.

Findings of this study emphasize the business case for sustainability as well as the increase of sustainability commitment and certification in tourism enterprises, and in particular, with tour operators. Moreover, it indicates support for increased promotion and awareness of sustainability certifications and their respective benefits for the firm and more broadly.

Author Contributions: The following are contributions by the authors A.H. and H.R.: Conceptualization (A.H. \& H.R.), Methodology (A.H. \& H.R.), Validation (A.H.), Formal Analysis (A.H.), Investigation (A.H.), Resources (A.H. \& H.R.), Data Curation (A.H.), Writing-Original Draft Preparation (A.H. \& H.R.), Writing-Review \& Editing (A.H. \& H.R.), Supervision (H.R.).

Funding: This research received no external funding.

Conflicts of Interest: The authors declare no conflict of interest. 


\section{References}

1. Friedman, M. The Social Responsibility of Business is to Increase its Profits. The New York Times Magazine, 13 September 1970.

2. Freeman, R.E. Strategic Management: A Stakeholder Approach; Cambridge University Press: Cambridge, UK, 1984.

3. Carasuk, R.; Becken, S.; Hughey, K.F. Exploring values, drivers, and barriers as antecedents of implementing responsible tourism. J. Hosp. Tour. Res. 2016, 40, 19-36. [CrossRef]

4. Dangelico, R.M.; Pujari, D. Mainstreaming green product innovation: Why and how companies integrate environmental sustainability. J. Bus. Ethics 2010, 95, 471-486. [CrossRef]

5. Font, X.; Garay, L.; Jones, S. Sustainability motivations and practices in small tourism enterprises in European protected areas. J. Clean. Prod. 2016, 137, 1439-1448. [CrossRef]

6. Vaugeois, N.; Goodwin, B.; Thuot, L.; Sliskovic, L.E.; Simmonds, G.; Whitney-Squire, K.F.; Faktor, A.; Young, J.; Simpson, T.; Borton, S.; et al. Made in BC: Innovation in Sustainable Tourism. Fostering Innovation in Sustainable Tourism. 2009. Available online: https://web.viu.ca/sustainabletourism/Innovation\% 20manual\%20Final\%20June\%204.pdf (accessed on 15 August 2018).

7. Jones, P.; Hillier, D.; Comfort, D. Sustainability in the global hotel industry. Int. J. Contemp. Hosp. Manag. 2014, 26, 5-17. [CrossRef]

8. Revell, A.; Stokes, D.; Chen, H. Small businesses and the environment: Turning over a new leaf? Bus. Strategy Environ. 2010, 19, 273-288.

9. Bonini, S.; Bové, A.-T. Sustainability's Strategic Worth: McKinsey Global Survey Results; McKinsey: New York, NY, USA, 2014; Available online: http://www.mckinsey.com/business-functions/sustainabilityand-resource-productivity / our-insights / sustainabilitys-strategic-worth-mckinsey-global-survey-results (accessed on 2 July 2017).

10. Dickinson, J.E.; Robbins, D.; Lumsdon, L. Holiday Travel Discourses and Climate Change. J. Transport Geogr. 2010, 18, 482-489. [CrossRef]

11. Miller, G.; Rathouse, K.; Scarles, C.; Holmes, K.; Tribe, J. Public understanding of sustainable tourism. Ann. Tourism Res. 2010, 37, 627-645. [CrossRef]

12. Higham, J.; Cohen, S.A.; Cavaliere, C.T.; Reis, A.C.; Finkler, W. Climate change, tourist air travel and radical emissions reduction. J. Clean. Prod. 2016, 111, 336-347. [CrossRef]

13. Gössling, S.; Hall, C.M.; Peeters, P.; Scott, D. The Future of Tourism: Can Tourism Growth and Climate Policy be Reconciled? A Mitigation Perspective. Tourism Recreation Res. 2010, 35, 119-130. [CrossRef]

14. Hall, C.M. Degrowing Tourism: Décroissance, Sustainable Consumption and Steady-State Tourism. Anatolia 2009, 20, 46-61. [CrossRef]

15. Dodds, R.; Graci, S.R.; Holmes, M. Does the tourist care? A comparison of tourists in Koh Phi Phi, Thailand and Gili Trawangan, Indonesia. J. Sustain. Tour. 2010, 18, 207-222. [CrossRef]

16. Doran, R.; Hanss, D.; Larsen, S. Attitudes, efficacy beliefs, and willingness to pay for environmental protection when travelling. Tour. Hosp. Res. 2015, 15, 281-292. [CrossRef]

17. Hultman, M.; Kazeminia, A.; Ghasemi, V. Intention to visit and willingness to pay premium for ecotourism: The impact of attitude, materialism, and motivation. J. Bus. Res. 2015, 68, 1854-1861. [CrossRef]

18. Lewis, T.; Cheung, O.; Jim, C.Y. Expectations and willingness-to-pay for ecotourism services in Hong Kong's conservation areas. Int. J. Sustain. Dev. World Ecol. 2014, 21, 149-159.

19. Pengwei, W.; Linsheng, Z. Tourist Willingness to Pay for Protected Area Ecotourism Resources and Influencing Factors at the Hulun Lake Protected Area. J. Resour. Ecol. 2018, 9, 174-180.

20. European Commission. Banking and Finance: Non-Financial Reporting; European Commission: Brussels, Belgium, 2016; Available online: http:/ / ec.europa.eu/finance/company-reporting/non-financial_reporting/ index_en.htm (accessed on 31 January 2017).

21. Dendler, L. Sustainability Meta Labelling: An effective measure to facilitate more sustainable consumption and production? J. Clean. Prod. 2014, 63, 74-83. [CrossRef]

22. UN General Assembly. Transforming Our World: The 2030 Agenda for Sustainable Development, 21 October 2015, A/RES/70/1. Available online: http:/ / www.refworld.org/docid/57b6e3e44.html (accessed on 7 November 2018). 
23. Armstrong, J.S.; Green, K.C. Effects of corporate social responsibility and irresponsibility policies. J. Bus. Res. 2013, 66, 1922-1927. [CrossRef]

24. Kang, K.H.; Lee, S.; Huh, C. Impacts of positive and negative corporate social responsibility activities on company performance in the hospitality industry. Int. J. Hosp. Manag. 2010, 21, 72-82. [CrossRef]

25. Barnett, M. Stakeholder influence capacity and the variability of financial returns to corporate social responsibility. Acad. Manag. Rev. 2007, 32, 794-816. [CrossRef]

26. Shen, C.H.; Chang, Y. Ambition versus conscience, does corporate social responsibility pay off? The application of matching methods. J. Bus. Ethics 2009, 88, 133-153. [CrossRef]

27. Esty, D.C.; Winston, A. Green to Gold: How Smart Companies Use Environmental Strategy to Innovate, Create Value, and Build Competitive Advantage; Wiley: Hoboken, NJ, USA, 2009.

28. Greening, D.; Turban, D. Corporate social performance as a competitive advantage in attracting a quality workforce. Bus. Soc. 2000, 39, 254-280. [CrossRef]

29. Molina-Azorín, J.F.; Claver-Cortés, E.; Pereira-Moliner, J.; Tarí, J.J. Environmental practices and firm performance: An empirical analysis in the Spanish hotel industry. J. Clean. Prod. 2009, 17, 516-524. [CrossRef]

30. Graci, S.; Dodds, R. Why Go Green? The Business Case for Environmental Commitment in the Canadian Hotel Industry. Anatolia Int. J. Tour. Hosp. Res. 2009, 19, 250-270. [CrossRef]

31. Hamann, E.; Habisch, A.; Pechlaner, H. Values that create value: Socially responsible business practice in SMEs: Empirical evidence from German companies. Bus. Ethics A Eur. Rev. 2009, 18, 37-51. [CrossRef]

32. Claver-Cortés, E.; Molina-Azorín, J.F.; Pereira-Moliner, J.; López-Gamero, M.D. Environmental strategies and their impact on hotel performance. J. Sustain. Tour. 2007, 15, 663-679. [CrossRef]

33. Chong, H.; Ricaurte, E. Hotel sustainability benchmarking. Cornell Hosp. Rep. 2014, 14, 6-21.

34. Aznar, J.P.; Sayeras, J.M.; Galiana, J.; Rocafort, A. Sustainability Commitment, New Competitors' Presence, and Hotel Performance: The Hotel Industry in Barcelona. Sustainability 2016, 8, 755-764. [CrossRef]

35. Atkinson, L.; Rosenthal, S. Signaling the Green Sell: The Influence of Eco-Label Source, Argument Specificity, and Product Involvement on Consumer Trust. J. Advert. 2014, 43, 33-45. [CrossRef]

36. Makower, J.; Pike, C. Strategies for the Green Economy: Opportunities and Challenges in the World of Business; McGraw-Hill: Columbus, OH, USA, 2009.

37. Center for Sustainable Tourism at East Carolina University. (n.d.). 10 Low to No-Cost Green Practices You Can Implement Today. Von Center for Sustainable Tourism. Available online: https:/ /www.ecu.edu/csacad/sustainabletourism/upload/10-Sustainable-Practices-You-can-Implement-Today.pdf (accessed on 15 August 2018).

38. Federation of Tour Operators. Travelife Sustainability Handbook. Travelife: Sustainability in Tourism. 2006. Available online: http:/ / www.travelife.org/tourism_business_new/documents/Supplier_Sustainability_ Handbook_English.pdf (accessed on 15 August 2018).

39. Kakaley, A.; Volkman, J.; Weaver, B.L. No-Cost/Low-Cost Energy Savings Guide; IFMA Foundation: Houston, TX, USA, 2010; Available online: https://www.fmi.gov/sites/default/files/NoCostLowCostGuide.pdf (accessed on 15 August 2018).

40. Reichel, A.; Haber, S. Identifying Performance Measures of Small Ventures: The Case of the Tourism Industry. J. Small Bus. Manag. 2005, 43, 257-287.

41. Akbaba, A. Business performance of small tourism enterprises: A comparison among three sub-sectors of the industry. Anatolia Int. J. Tour. Hosp. Res. 2012, 23, 177-195. [CrossRef]

42. DeBusk, S. Hotels Install Window Film to Increase Energy Efficiency. 2015. Available online: https: / / www.llumar.com/window-film-blog/commercial-window-film-blog-llumar/hotels-installwindow-film-to-increase-energy-efficiency (accessed on 15 August 2018).

43. Esty, D.C.; Simmons, P.J. The Green to Gold Business Playbook: How to Implement Sustainability Practices for Bottom-line Results in Every Business Function; Wiley: Hoboken, NJ, USA, 2011.

44. Brebbia, C.A.; Pineda, F.D. Sustainable Tourism; WIT Press: Boston, MA, USA, 2004.

45. Budeanu, A. Impacts and responsibilities for sustainable tourism: A tour operator's perspective. J. Clean. Prod. 2005, 13, 89-97. [CrossRef]

46. Forum for the Future and The Travel Foundation. Survival of the Fittest: Sustainable Tourism Means Business; Forum for the Future and The Travel Foundation: Bristol, UK, 2012. 
47. TripAdvisor. Tripadvisor Survey Revelas Travelers Growing Greener; TripAdvisor: Needham, MA, USA, 2012; Available online: http://www.multivu.com/mnr/49260-tripadvisor-eco-friendly-travel-surveyvoluntourism-go-green (accessed on 15 August 2018).

48. Kwan, H.; Liu, H.; Mak, H. Willingness to Pay for Responsible Travel; Ryerson University: Toronto, ON, Canada, 2014.

49. Adlwarth, W. Corporate Social Responsibility-Customer Expectations and Behaviour in the Tourism Sector: Trends and Issues in Global Tourism; Springer-Verlag: Berlin/Heidelberg, Germany, 2010.

50. López-Sánchez, Y.; Pulido-Fernández, J.I. In search of the pro-sustainable tourist: A segmentation based on the tourist "sustainable intelligence". Tour. Manag. Perspect. 2016, 17, 59-71. [CrossRef]

51. World Travel \& Tourism Council. Travel \& tourism 2015: Connection Global Climate Action; World Travel \& Tourism Council: London, UK, 2015.

52. Makower, J. Green Marketing Is Over. Let's Move On; Greenbiz: Oakland, CA, USA, 2011; Available online: http:/ / www.greenbiz.com/blog/2011/05/16/green-marketing-over-lets-move?page=full (accessed on 15 August 2018).

53. Crane, A. Marketing and the Natural Environment: What Role for Morality. J. Macromarketing 2000, 20, 144-154. [CrossRef]

54. Leire, C.; Thidell, Å. Product-related environmental information to guide consumer purchases-A review and analysis of research on perceptions, understanding and use among Nordic consumers. J. Clean. Prod. 2005, 13, 10-11. [CrossRef]

55. Peattie, K.; Crane, A. Green marketing: Legend, myth, farce or prophesy? Qual. Mark. Res. Int. J. 2005, 8, 357-370. [CrossRef]

56. Gössling, S.; Buckley, R. Carbon labels in tourism: Persuasive communication? J. Clean. Prod. 2016, 111, 358-369. [CrossRef]

57. Font, X.; Elgammal, I.; Lamond, I. Greenhushing: The deliberate under communicating of sustainability practices by tourism businesses. J. Sustain. Tour. 2017, 25, 1007-1023. [CrossRef]

58. Nyilasy, G.; Gangadharbatla, H.; Paladino, A. Perceived Greenwashing: The Interactive Effects of Green Advertising and Corporate Environmental Performance on Consumer Reactions. J. Bus. Ethics 2014, 125, 693-707. [CrossRef]

59. Villarino, J.; Font, X. Sustainability marketing myopia: The lack of persuasiveness in sustainability communication. J. Vacat. Mark. 2015, 8, 277-296. [CrossRef]

60. Ottman, J.A. The New Rules of Green Marketing: Strategies, Tools, and Inspiration for Sustainable Branding; Berrett-Koehler Publishers: San Francisco, CA, USA, 2011.

61. Roberts, J.A. Green consumers in the 1990s: Profile and implications for advertising. J. Bus. Res. 1996, 36, 217-231. [CrossRef]

62. Hardeman, G.; Font, X.; Nawijn, J. The power of persuasive communication to influence sustainable holiday choices: Appealing to self-benefits and norms. Tour. Manag. 2017, 59, 484-493. [CrossRef]

63. Kim, S.B.; Kim, D.Y. The effects of message framing and source credibility on green messages in hotels. Cornell Hosp. Q. 2014, 55, 64-75. [CrossRef]

64. Griskevicius, V.; Tybur, J.M.; Van den Bergh, B. Going green to be seen: Status, reputation, and conspicuous conservation. J. Personal. Soc. Psychol. 2010, 98, 392-404. [CrossRef] [PubMed]

65. Ottman, J.A.; Stafford, E.R.; Hartman, C.L. Avoiding green marketing myopia: Ways to improve consumer appeal for environmentally preferable products. Environ. Sci. Policy Sustain. Dev. 2006, 48, 22-36. [CrossRef]

66. Becker-Olsen, K.L.; Cudmore, B.A.; Hill, R.P. The impact of perceived corporate social responsibility on consumer behavior. J. Bus. Res. 2006, 59, 46-53. [CrossRef]

67. Delmas, M.A.; Nairn-Birch, N.; Balzarova, M. Choosing the right eco-label for your product. MIT Sloan Manag. Rev. 2013, 4, 10-12.

68. Big Room Inc. Ecolabel Index. 2017. Available online: http://www.ecolabelindex.com (accessed on 1 February 2017).

69. Hamele, H. DestiNet: Mehr Transparenz im nachhaltigen Tourismus. In Tourismus in Entwicklungs- und Schwellenländer; (S. 239-240); Studienkreis für Tourismus und Entwicklung: Seefeld, Austria, 2013.

70. Ramos, M.J. CBSR Blog: CSR as a Driver of Employee Engagement; 3BL Media: Northampton, MA, USA, 2012; Available online: http:/ /3blmedia.com/theCSRfeed/CBSR-Blog-CSR-Driver-Employee-Engagement (accessed on 15 August 2018). 
71. Wirtenberg, J. Building a Culture for Sustainability: People, Planet, and Profits in a New Green Economy; Praeger: Santa Barbara, CA, USA, 2014.

72. Society for Human Resource Management. Advancing Sustainability: HR's Role: A Research Report by the Society for Human Resource Management, BSR and Aurosoorya; Society for Human Resource Management: Alexandria, VA, USA, 2011.

73. Vitaliano, D.F. Corporate social responsibility and labor turnover. Corp. Gov. Int. J. Bus. Soc. 2010, 10, 563-573. [CrossRef]

74. Wrzesniewski, A.; McCauley, C.; Rozin, P.; Schwartz, B. Jobs, Careers, and Callings: People's Relations to Their Work. J. Res. Pers. 1997, 31, 21-33. [CrossRef]

75. Wrzesniewski, A. Finding Positive Meaning in Work. In Positive Organizational Scholarship: Foundations of a New Discipline; Cameron, K.S., Dutton, J.E., Quinn, R.E., Eds.; Berrett-Koehler Publishers: San Francisco, CA, USA, 2003; pp. 296-308.

76. Delmas, M.A.; Pekovic, S. Environmental standards and labor productivity: Understanding the mechanisms that sustain sustainability. J. Organ. Behav. 2013, 34, 230-252. [CrossRef]

77. Dumitrescu, L.; Stanciu, O.; Tichindelean, M.; Vinerean, S. Achieving employee satisfaction by pursuing sustainable practices. Stud. Bus. Econ. 2013, 8, 36-45.

78. Tourism Watch. A Guide through the Tourism Label Jungle. 2016. Available online: https://www.tourismwatch.de/en/content/guide-through-tourism-label-jungle (accessed on 15 August 2018).

79. Dunphy, D.; Griffiths, A.; Benn, S. Organizational Change for Corporate Sustainability; Routledge: Oxfordshire, UK, 2003.

80. Jones, P.; Hillier, D.; Comfort, D. Sustainability in the hospitality industry: Some personal reflections on corporate challenges and research agendas. Int. J. Contemp. Hosp. Manag. 2016, 28, 36-67. [CrossRef]

81. The Nielsen Company. Consumer-Goods' Brands That Demonstrate Commitment to Sustainability Outperforme Those That Don't; Nielsen: New York, NY, USA, 2015; Available online: http: / / www.nielsen.com/ca/en/press- / room/2015/consumer-goods-brands-that-demonstrate-commitmentto-sustainability-outperform.html (accessed on 15 August 2018).

82. Kachel, U.; Jennings, G. Exploring tourists' environmental learning, values and travel experiences in relation to climate change: A postmodern constructivist research agenda. Tour. Hosp. Res. 2010, 10, 130-140. [CrossRef] 